\title{
Treatment of Paint (Emulsion) Industry Wastewater by Electrocoagulation
}

\author{
Namrata S Gajjar ${ }^{1}$, Ms Neha Patel ${ }^{2}$ \\ 1.P.G.Student(Environmental Engineering) 2.Associate Professor \\ Birla Vishvakarma Mahavidhyalaya Engineering College, Vallabh Vidyanagar-388120.
}

\begin{abstract}
Treatment of paint industry (emulsion) wastewaters by electrocoagulation using different electrode materials has been investigated in this paper. Several working parameters, such as $\mathrm{pH}$, current density, operating time, types of electrodes and surface area were studied in an attempt to achieve a higher COD removal capacity. The electrolytic cell used was a $500 \mathrm{ml}$ cylinder glass reactor with working volume $400 \mathrm{ml}$ and equipped by magnetic stirrer without temperature control. The DC power supply was controlled by a voltmeter. The study also revealed that electrocoagulation with Al electrodes was more effective than MS and SS electrodes.
\end{abstract}

Key words: electrocoagulation, paint industry waste water, electrolytic cell, electrodes.

\section{Introduction}

India's strong economic growth has propelled the paint industry to double-digit growth over the past few years. Due to increased Government funding for infrastructure, demand for paints both in industrial and decorative segment is set to rise, thereby rendering Indian paint industry to be poised for further growth.

Satisfactory disposal of wastewater, whether by surface, subsurface methods or dilution, is dependent on its treatment prior to disposal. Adequate treatment is necessary to prevent contamination of receiving waters to a degree which might interfere with their best or intended use, whether it be for water supply, recreation, or any other required purpose.

In the electrocoagulation process, the coagulants are generated electrically and wastewater is treated in an electrochemical cell. When the system is connected to an external power source, sacrificial anodes are corroded due to oxidation in the solution and release coagulant cations (usually aluminium or iron) in the cell.

This study, the treatability of paint industry(emulsion) waste water by the EC method was tested, and the COD removal efficiency were determined.

\section{Materials And Methods}

The wastewater was obtained from a local paint industry. The effect of various process variables such as electrode material, surface area, distance between two electrodes and operating time was investigated. The electrolytic cell used was a $500 \mathrm{ml}$ cylinder glass reactor with working volume $400 \mathrm{ml}$ and equipped by magnetic stirrer without temperature control. Two aluminium plates were used as anode/cathode pair. The distance between two electrodes was $3 \mathrm{~cm}$ and $4 \mathrm{~cm}$. The DC power supply was used and be adjusted constant at $240 \mathrm{~mA}$ for most test runs.

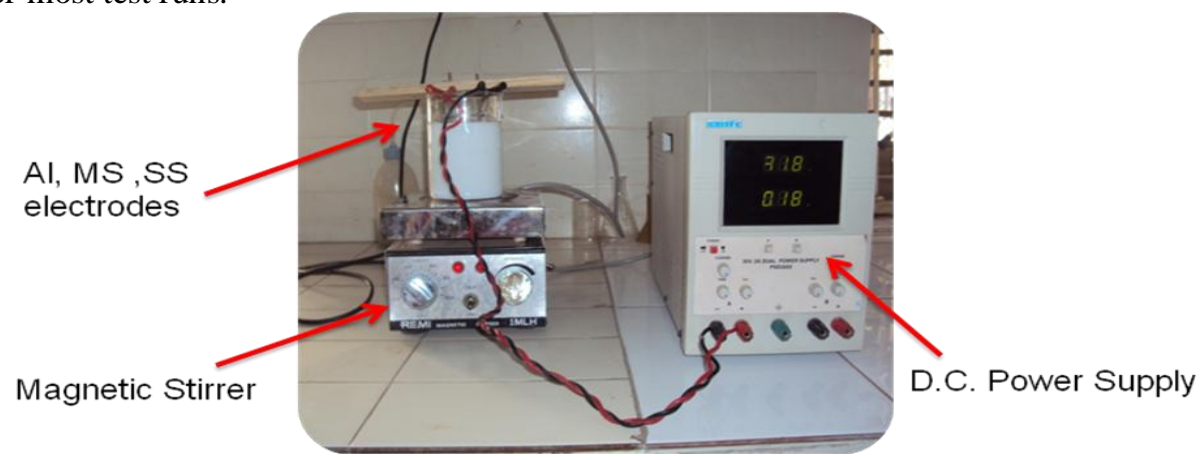

Fig.1 Experimental set up

For each test run, $400 \mathrm{~mL}$ of waste water was put in the reactor. Wastewater samples were taken at different time intervals and filtered before analyzed. The water quality of paint industry waste water, such as the COD, $\mathrm{pH}$, suspended solid and was measured in each experimental run by the standard methods APHA (1992). 


\section{Effect of electrode material}

\section{Results And Discussion}

Different types of electrode material such as Aluminium, MS and SS were used for the treatment of paint industry waste water. The effluent was treated with different electrode materials to obtain higher COD removal efficiency. The experimental results showed that higher COD removal efficiency obtained with Al electrodes.

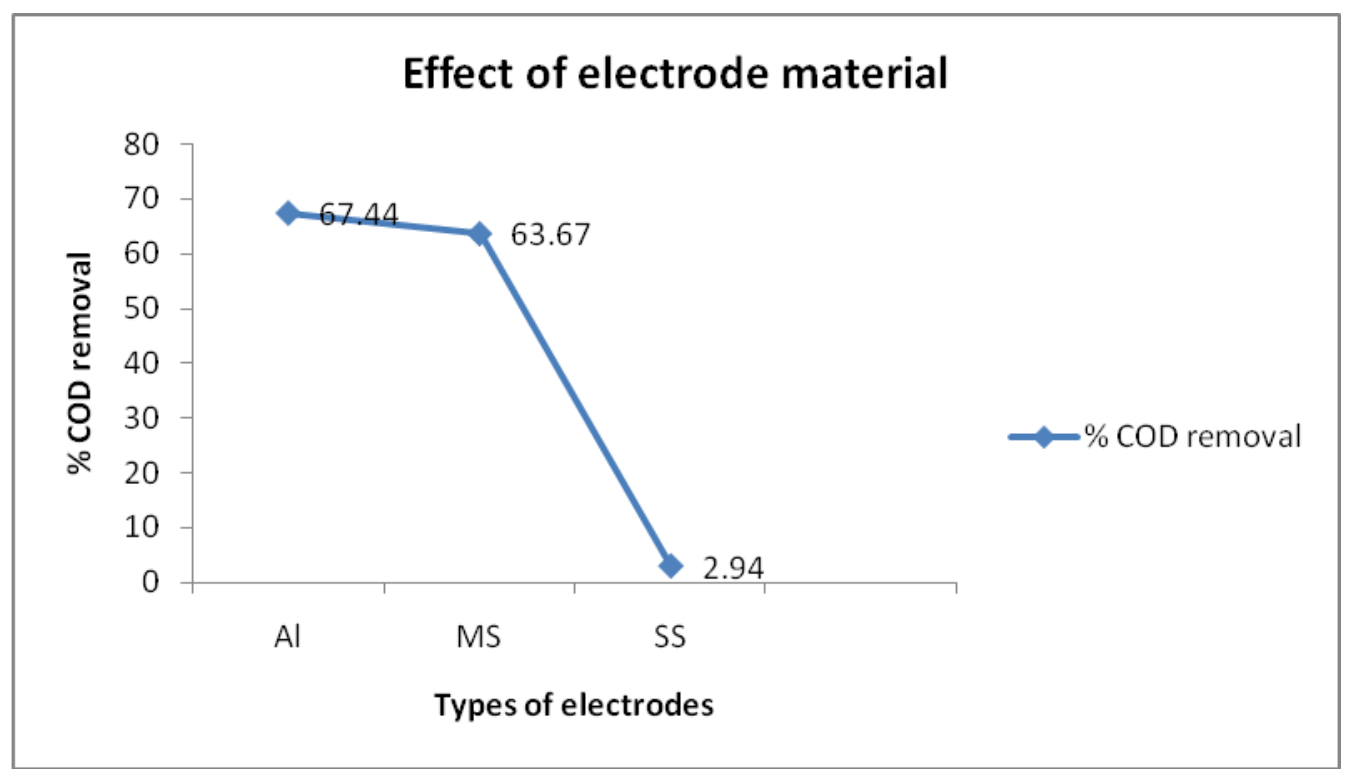

Fig.2 Effect of electrode material on COD removal

\section{Effect of Operating Time}

The effect of time was studied at constant current density of $240 \mathrm{~mA}$ with two $\mathrm{Al}$ electrodes. Figure illustrates the removal of COD as a function of operating time. It is clearly seen from Fig that, the operating time has a significant effect on the pollutant removal. When the operating time changed from 10 to 40 minute, maximum COD removal efficiency was obtained within $20 \mathrm{~min}$.

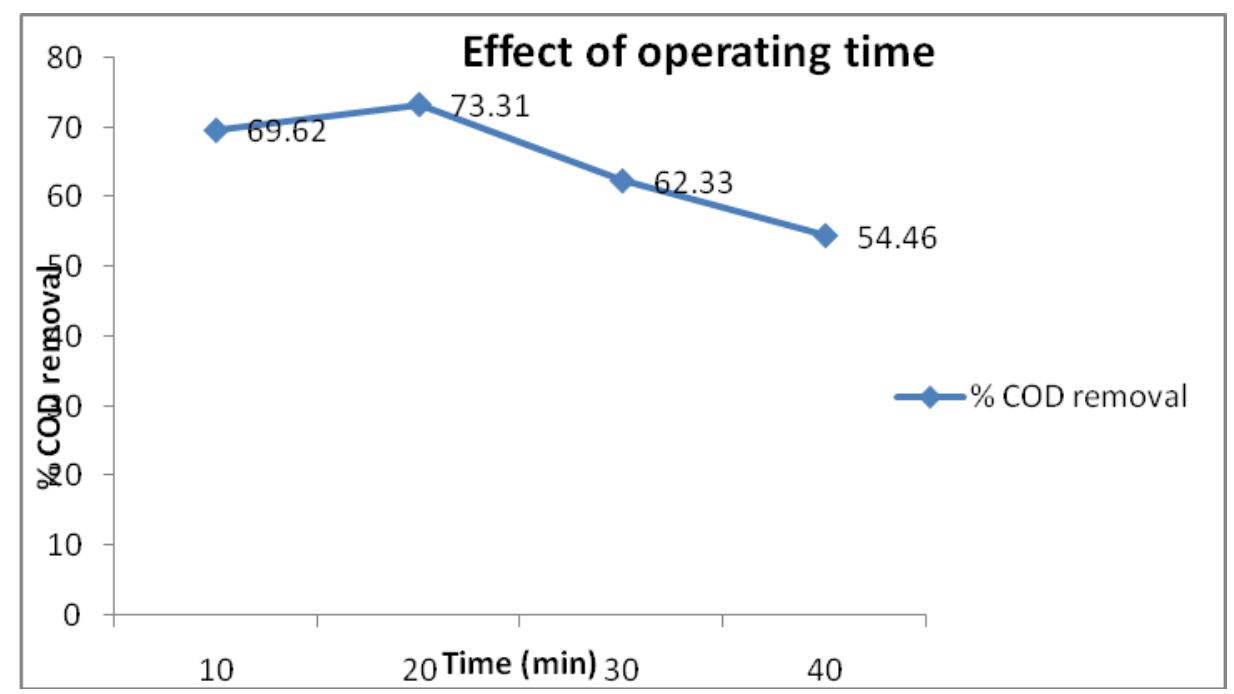

Fig.3 Effect of operating time on COD removal

\section{Effect of ph}

The effect of $\mathrm{pH}$ on the COD removal as shown in Fig, was investigated with the applied current of $240 \mathrm{~m} \mathrm{~A}$ and operating time at 20 minutes. At neutral pH higher COD removal efficiency was obtained. 


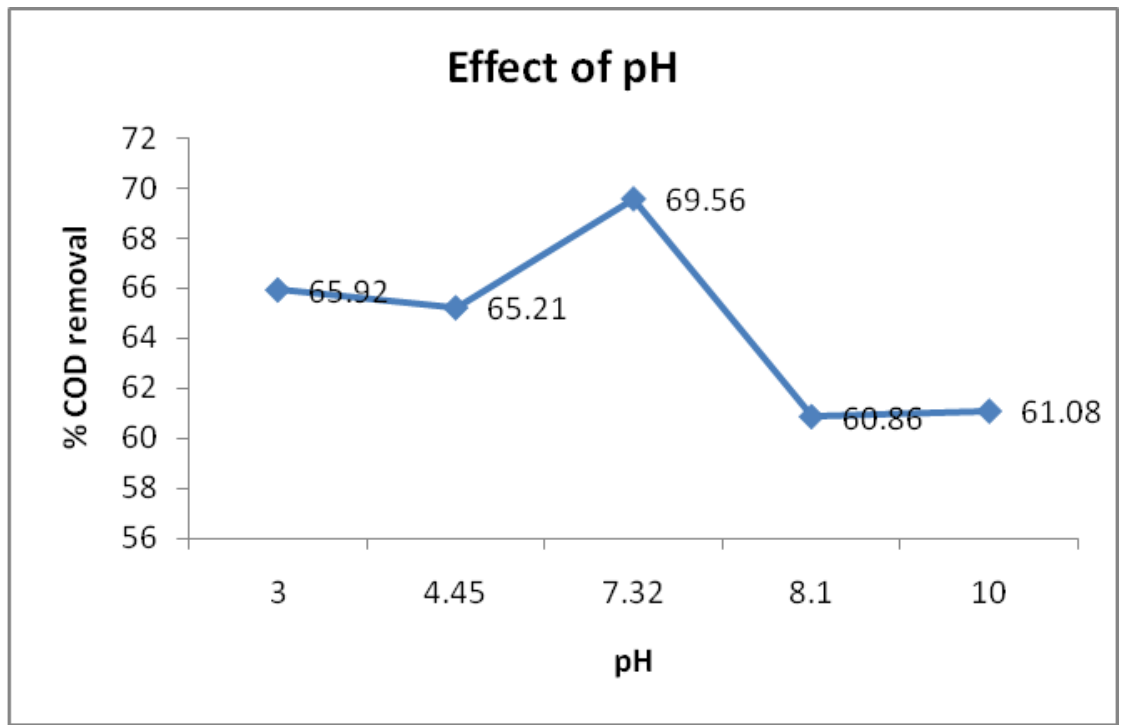

Fig.4 Effect of pH on COD removal

\section{Effect of surface area}

The effect of surface area on the COD removal was investigated. Other parameters were kept constant and surface area used was $30 \mathrm{~cm} 2,60 \mathrm{~cm} 2$. The higher efficiency was obtained with surface area of $60 \mathrm{~cm} 2$.

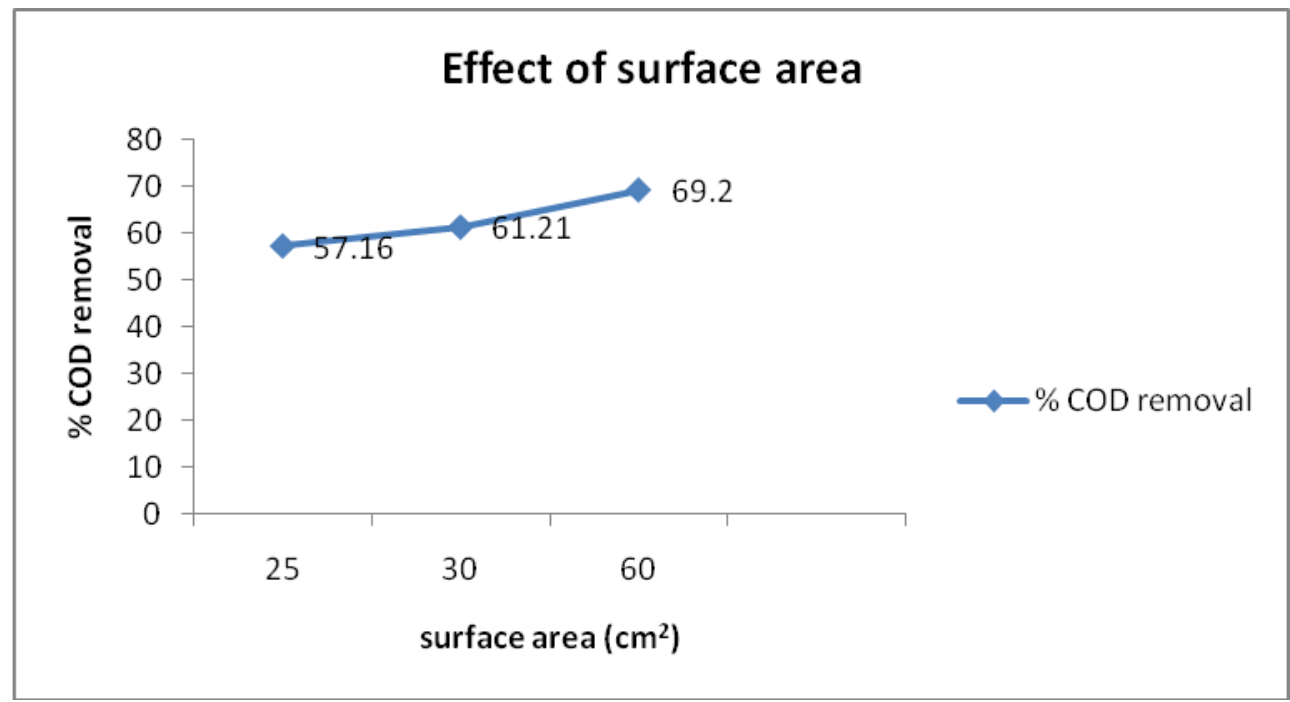

Fig.5 Effect of surface area on COD removal

\section{Conclusion}

In this lab-scale study, high COD removal efficiency was achieved using electrocoagulation technique for the treatment of Paint(emulsion) industry waste water.The results show that the COD removal efficiency is as high as $73.31 \%$ for EC process with current density of $8 \mathrm{~mA} / \mathrm{cm} 2$ and retention time of $20 \mathrm{~min}$. Experimental results show that, electrocoagulation technique has the potential to treat the paint (emulsion) wastewater.

\section{References}

[1]. Akyol A,“ Treatment of paint manufacturing wastewater by electrocoagulation”, Gebze Institute of Technology, Department of Environmental Engineering,Cayırova, Turkey,2011.

[2]. Ni'am M.F, Othman F, Sohaili J,Fauzia Z, "Removal of COD and turbidity to improve wastewater quality using electrocoagulation technique", The Malaysian Journal of Analytical Sciences, 2007,Vol 11, No 1.

[3]. Tezcanun U and Aytac E, "Treatment of Textile Wastewaters by Electrocoagulation Method", 2nd International Conference on Chemical Engineering and Applications, 2011, vol. 23.

[4]. Secula M.S, Crețescu I, Petrescu S, "Separation of sulfides from aqueous solution by electrocoagulation"“"Gheorghe Asachi” Technical University of Iasi, Faculty of Chemical Engineering and Environmental Protection, 73 Prof. Dr. Doc. D. Mangeron, 700050, Iasi, Romania

[5]. Apaydin O,Gonullu M.T, “An investigation on the treatment of tannery wastewater by electrocoagulation",Global NEST Journal, Turkey,2009 Vol 11, No 4. 
[6]. Budiyono,Widiasa I.N, and Johari S, “ Study on Treatment of Slaughterhouse Wastewater by Electro-coagulation Technique" Internat. J. of Sci. and Eng., July 2010, Vol. 1(1).

[7]. Kurt U,Gonullu M.T, Ilhan F, Varinca K, "Treatment of Domestic Wastewater by Electrocoagulation in a Cell with Fe-Fe Electrodes", environmental engineering science,Turkey,2008, volume 25.

[8]. Kobya M, Can O.T, Bayramoglu M, "Treatment of textile wastewaters by electrocoagulation using iron and aluminum electrodes", Journal of Hazardous Materials, Turkey,2003.

[9]. Sarala C, "Domestic Wastewater Treatment by Electrocoagulation with Fe-Fe Electrodes", International Journal of Engineering Trends and Technology, India, 2012, Volume3.

[10]. Ilhan F, Kurt U , Apaydin O , M.Gonullu M.T, "Treatment of leachate by electrocoagulation using aluminum and iron electrodes", Journal of Hazardous Materials, Turkey,2008.

[11]. Dermentizisi K, Christofridis A, Valsamidou E, Lazaridou A, Kokkinos N, “ Removal of hexavalent chromium from electroplating wastewater by elecrocoagulation with iron electrodes", Global NEST Journal,Greece, 2011,Vol 13, No 4.

[12]. Babu B.R, Meera K.M, and Venkatesan P, "Removal of pesticides from wastewater by electrochemical methods- A comparative approach", Pollution Control Division, CSIR- Central Electrochemical Research Institute, Karaikudi,India.

[13]. Alaton I.A, Kabdaslı I, and Sahin Y, "Effect of Operating Parameters on the Electrocoagulation of Simulated Acid Dyebath Effluent", The Open Environmental \& Biological Monitoring Journal, 2008.

[14]. Xu X, Zhu X, "Treatment of refectory oily wastewater by electro-coagulation process", Department of Environmental Engineering, ZhejiangUniversity, China,2004.

[15]. Byung R. Kim,"VOC Emissions from Automotive Painting and Their Control: A Review", Department of Environmental Engineering and Biotechnology, Myongji University,Korea,2011

[16]. T. Sasikala," Corrosion Behavior of Medium Carbon Steel in Paint Industrial Effluent”, Environmental Economics eJournal,2010.

[17]. APHA, AWWA and WPCF 1995, "Standard methods for the Examination of water and wastewater". 19th edition, jointly edited by Eaton, A.D.; Clesceri, L.S. and Grreenberg, A.E. 